\title{
Anti-inflammatory effect of dexamethasone tablets orally administered in dogs determined by the tissue chamber model
}

\begin{abstract}
Anti-inflammatory effects of dexamethasone tablets* were evaluated using a tissue cage model of inflammation in dogs. Multi perforated polypropylene balls were inserted subcutaneously in the scapula region of eight healthy Beagle dogs (males and females) randomly assigned in to the crossover study design. The mild inflammatory reaction was induced by intracaveal injection of $0.5 \mathrm{~mL}$, of a $2 \%$ carrageenan. The product dexamethasone was administered orally* $(0.25 \mathrm{mg} / \mathrm{animal})$ at $30 \mathrm{~min}$ after induction inflammation. Clinical, hematological and biochemical parameters were analyzed during the study period. Tissue cages exudate was sampled at predetermined times (up to $48 \mathrm{~h}$ ) to measure exudate volume and exudate $\mathrm{PGE}_{2}$ concentration. Antiinflammatory efficacy was assessed by comparison between the $\mathrm{PGE}_{2}$ concentration results and the mean exudate volume on samples collected. Statistical differences $(\mathrm{p}<0.05)$ were found at $4 \mathrm{~h}, 8 \mathrm{~h}, 12 \mathrm{~h}, 24 \mathrm{~h}$ and $48 \mathrm{~h}$ for lower exudate volume collected in the test group in comparison to the control group exudate volume. Exudate Prostaglandin $\left(\mathrm{PGE}_{2}\right)$ concentration values were statistically different $(\mathrm{p}<0.05)$ comparing the test and the control group at $12 \mathrm{~h}, 24 \mathrm{~h}$ and $48 \mathrm{~h}$ after inflammation induction, whereas lower $\mathrm{PGE}_{2}$ concentration was observed in the test group. The results indicate that the Cortvet Pet ${ }^{*}$ (dexamethasone) exhibits anti-inflammatory effects by inhibiting $\mathrm{PGE}_{2}$ production.
\end{abstract}

Keywords: dogs, anti-inflammatory, dexamethasone, prostaglandin, $\mathrm{PGE}_{2}$, tissue cage model
Volume 6 Issue 3 - 2018

\author{
Andrade Gisele Maria de,' Marchiori Filho \\ Moacir,' Machado Gláucio Pereira, ${ }^{2}$ Almeida \\ Diego Salgado de Almeida, ${ }^{2}$ Girio Thaís \\ Marino Silva,' Brunini Marcelo, ${ }^{3}$ Leonelo \\ Neto Armando,' Ré Raquel Amador' \\ 'Department of Research and Development (Pharmacist, \\ Physical-Chemical and Technical), UCBVET Saúde Animal, Brazil \\ ${ }^{2}$ Laboratorios Ecolyzer Ltda, Brazil \\ ${ }^{3}$ President, UCBVET Saúde Animal, Brazil
}

Correspondence: Gisele Maria de Andrade, UCBVET Saúde Animal, Praça Dr. Joaquim Batista, I50, Centro, CEP |4870-090, Jaboticabal, São Paulo, Brazil, Tel +55-16 -3209-4222, Email gisele@ucbvet.com.br

Received: April 27, 2018 | Published: June 22, 2018

\section{Introduction}

Glucocorticoids according Godman \& Gilman, ${ }^{12}$ steroid hormones are naturally synthesized in the cortex of the adrenal gland. Synthetic glucocorticoids are similar to natural ones because of their chemical structure and are used as anti-inflammatory drugs for different purposes. ${ }^{5}$ They have a wide use, but are mainly used in the veterinary clinic because of its anti-inflammatory and immunosuppressive effects. They inhibit both early and late manifestations of inflammation, ie not only initial redness, heat, pain and swelling, but also the later stages of wound healing and repair and proliferative reactions observed in the inflammatory process chronic. ${ }^{5} \mathrm{~S}$ will also employed for the treatment of specific medical conditions such as anaphylactic shock, diffuse cerebral edema, autoimmune and immune - mediated diseases, hypersensitivity reactions and acetonemia in dairy cows. ${ }^{17,20}$ One of the mechanisms of anti-inflammatory action of glucocorticoids occurs by the inhibition of the enzyme phospholipase $A_{2}$, thus preventing the release of arachidonic acid and the subsequent cascade that will give rise to mediators of infamation, such as prostaglandin and leukotriene metabolites. ${ }^{3,6}$ In addition, glucocorticoids regulate functions of immune system cells, have the ability to inhibit specific leukocyte functions, including inhibition of lipolytic and proteolytic enzymes, release of chemotactic substances, mediators involved in increased vascular permeability, and glucorticoids also interfere with vasodilation and contraction of several non-vascular smooth muscles, in addition to interfering with $\mathrm{n}$ the humoral and cellular immune response. ${ }^{6,24}$ In the control of inflammation, steroidal antiinflammatory drugs are classified into fast-acting, intermediate-acting or long-acting corticosteroids, according to their potency and duration of effects. They are able to block from the earlier manifestations of the inflammatory process, such as pain, heat and redness, until the later responses such as repair and tissue proliferation. ${ }^{5}$

Dexamethasone is a synthetic glucocorticoid widely used for in vitro and in vivo studies on the effects on different cellular and physiological responses. ${ }^{8}$ It is approximately five to 10 times more potent than prednisolone, ${ }^{9}$ and with an action time of approximately 32 to 48hours. Dexamethasone has an immunosuppressive effect and acts both in the early and late manifestations of the inflammatory process. ${ }^{1}$ Its action occurs mainly due to the inhibition of cell migration to the affected area, by suppressing the expression of adhesion molecules, or by inducing the synthesis of the phospholipase $A_{2}$ inhibitory protein the enzyme responsible for the release of arachidonic acid. In veterinary clinical, physiological disorders and diseases such as inflammation, acetonemia, ketosis, anaphylactic shock, fatty liver syndrome and stress are commonly treated using dexamethasone. ${ }^{2,4}$ It is also indicated both in human medicine and in veterinary medicine for the treatment of respiratory distress syndrome. ${ }^{19,22}$ Dexamethasone is on the list of essential medicines of the World Organization (WHO), and is among the most important medications necessary for the basic health system. ${ }^{31}$ Acute or chronic inflammation models are used to investigate the changes that occur during the inflammatory process, as well as to identify potentially useful drugs such as antiinflammatories. The tissue camera models of acute inflammation were developed by Higgins \& LESS $^{18}$ and collaborators to facilitate the study of the role of eicosanoids and other mediators involved in the inflammatory process, in addition to understanding the mechanism 
of action of nonsteroidal and steroidal anti-inflammatory drugs. ${ }^{13,21} \mathrm{~A}$ mild, reproducible and sterile inflammatory process is produced using as an inflammatory stimulus carra genin, a sulphated polysaccharide obtained from some species of red algae of the order Gigartinales ${ }^{16,32}$ ). After the injection of carrageenan, the alterations resulting from the inflammatory process induced by the action of several inflammatory mediators. ${ }^{28}$ Prostaglandins, particularly $\mathrm{PGE}_{2}$ and $\mathrm{PGI}_{2}$ derivative of metabolism of arachidonic acid and the enzyme produced by ciclogenase, lipid mediators are important participants in the inflammatory process. ${ }^{11} \mathrm{PGE}_{2}$ recognized as an active mediator of inflammation, promotes vasodilatation, local attraction and activation of neutrophils, macrophages, and mast cells in the early stages of inflammation. . $^{29,30}$

Because the induced inflammatory process is transient and located in a region of the body, this model of acute process with the tissue chamber implant has been accepted ethically and because it causes minimal stress in the animal. The spherical chamber composed of polypropylene contains perforations to allow the collection of exudate. The objective of the present study was to evaluate the antiinflammatory efficacy of the product Cortvet Pet ${ }^{\circledR}$ tablet (UCBVET Saúde Animal), containing dexamethasone, in dogs submitted to the experimentally induced inflammatory process through surgical implantation of a polypropylene tissue compartment in the format perforated ball for artificial induction of the inflammatory process by carrageenan and subcutaneous exudate collection.

\section{Materials and methods}

The experimental protocol of the present study was approved by the Ecolyzer Ethics Committee on Animal Use.(CEUA No. 00042/12).

\section{Animals}

Eight Beagle dogs from the Ecolyzer experimental kennel males and females, aged 12 to 18 months, mean weight of $12.35 \mathrm{~kg} \pm 1.447$ and identified by microchips, were used in this study. The dogs were allocated in two groups of 4 dogs each (2females and 2males), in a randomized, cross over design, with repeated measures in time, where the animal of the test group (treated) in the period 1 came to belong to the control group in period 2 and vice versa, as described in the scheme of Table 1. The dogs were kept in masonry kennel, in collective stalls, fed twice daily with commercial dog food, and free access to water. The animals had not received any previous anti-inflammatory medication for 14days prior to the start of the experiment. At the end of this study animals returned to the experimental kennel.

Table I Distribution of experimental animals in cross over design

\begin{tabular}{ll}
\hline Period I & \\
Group I (PI) & Test group $(n=4)$ \\
Group 2(PI) & Control group $(n=4)$ \\
Period 2 & \\
Group 2(P2) & Test group $(n=4)$ \\
Group I (P2) & Control group $(n=4)$ \\
\hline
\end{tabular}

\section{Implantation of the tissue compartment}

Twenty-one days before inflammatory induction and treatment (D21 ), the surgical implantation of a polypropylene tissue compartment in the sphere format containing perforations was performed to induce the inflammatory process and exudate collection. Before the surgical procedure, the region of the scapula was prepared through the tricotomy with a disposable razor blade and local antisepsis with iodized alcohol. The dogs were then anesthetized with xylazine to $2 \%(2 \mathrm{mg} / \mathrm{kg})$, intramuscularly, quetamine at $10 \%(5 \mathrm{mg} / \mathrm{kg})$ and diazepam $(0.5 \mathrm{mg} /$ $\mathrm{kg}$ ) intravenously. The sterile propylene implant was placed in each animal in the subcutaneous tissue of the region of the scapula, on the left side of the animal. The animals were observed for the state of health until the complete healing of the implantation site, which occurred 22 days after the surgical procedure. If any animal had any symptoms, it would be examined, medicated if necessary and excluded from the experiment.

\section{Induction of local inflammation and treatment}

At day D0 of the study, for induction of local inflammation, $0.5 \mathrm{~mL}$ of a sterile $2 \%$ solution of carrageenin was injected into each tissue compartment. Thirty minutes after the induction of inflammation with carrageenan, the Cortvet Pet ${ }^{\circledR}$ tablet product (UCBVET Saúde Animal) was administered to the animals of the test group (periods 1 and 2) orally at a dose of $0.25 \mathrm{mg}$ for each animal. And drug administration in period 1 in D0; and in period 2 in the D+29 of the study. Animals of the control group (periods 1 and 2) were not medicated.

\section{Sampling for analysis}

Samples of blood $(5 \mathrm{~mL})$ from each animal were collected at study times D-7 and D+22 for the determination of laboratory parameters (hematological and serum biochemistry).Urine samples were obtained by bladder catheterization with the aid of sterile plastic catheter connected to a sterile plastic syringe, with the animal properly contained. The collection of the inflammatory exudate directly from the inside of the tissue compartments of each animal was performed using disposable syringes and needles at $30 \mathrm{~min}, 01 \mathrm{~h} 30 \mathrm{~min}, 4 \mathrm{~h} ; 8 \mathrm{~h}$, $12 \mathrm{~h}, 24 \mathrm{~h}$ and $48 \mathrm{~h}$ after administration of the Cortvet Pet $^{\mathbb{B}}$ product in the test group (periods 1 and 2). The exudate volume ( 1 to $2 \mathrm{~mL}$ ) was recorded, identified and maintained at $-20^{\circ} \mathrm{C}$ until the assay of prostaglandin $\mathrm{PGE}_{2}$.

\section{Clinical and laboratory tests}

Clinical exams consisted of evaluation of heart rate, respiratory rate, rectal temperature, all performed on days D-7 (pre-test of period 1) and D22 (pre-test of period 2). The hematological and biochemical parameters analyzed consisted of: complete blood count, dosage of the enzymes alanine aminotransferase (ALT), aspartate aminotransferase (AST), gamma glutamyltransferase (GGT), alkaline phosphatase , direct and total bilirubin, $(\mathrm{pH}$, albumin, glucose, ketone bodies, bilirubin, urobilinogen, hemoglobin, myoglobin, leukocyte and nitrite) and in the urinalysis the physical parameters (volume, color, odor, appearance, consistency) sedimentoscopy (cells, erythrocytes, leukocytes, cylinders, crystals and bacteria). The prostaglandin E2 $\left(\mathrm{PGE}_{2}\right)$ dosage was performed in the inflammatory exudates harvested at the times determined during the experiment by use of monoclonal EIA kit (enzyme immunoassay).

\section{Statistical analysis}

The SPSS Statistics 17.0 software was used to analyze the data, and the level of significance was set at $\mathrm{p}<0.05$. Considering the application of the $\mathrm{T}$ test for the evaluation of clinical, hematological parameters, inflammatory exudate and urinalysis. 


\section{Results and discussion}

In the present study, the results of clinical exams performed at periods 1 in $\mathrm{D} 7$ and 2 in $\mathrm{D}+22$ remained normal, within the expected values for the canine species, when the means of vital parameters were compared, with no difference between the control and test groups. There was also no significant difference $(\mathrm{p}>0.05)$ for most of the haematological and urinary parameters analyzed. On the other hand, the result of the eosinophils parameter showed a significant difference $(p<0.05)$ between the groups, being the test group with the highest number of eosinophils in relation to the control group in the pre-test (D-7) in period 1, although the difference was found within the expected values for the canine species. ${ }^{15}$ The antiinflammatory efficacy was verified from the comparative analysis between the results of the concentration of prostaglandin $\left(\mathrm{PGE}_{2}\right)$ and the volume of inflammatory exudate in the samples collected from the test and control groups after administration of the tested product. For the mean volume of the exudates collected from the tissue implants of the test and control groups, in periods 1 and 2 after administration of the product containing dexamethasone, statistical differences were found in the $4 \mathrm{~h}$ times; $8 \mathrm{~h} ; 12 \mathrm{~h}, 24 \mathrm{~h}$, and $48 \mathrm{~h}$ (Table 2) (Figure 1). The average volume collected found for the test group was 1.09 $\mathrm{mL} 4 \mathrm{~h}$ and $0.48 \mathrm{ml}$ in 48 hours, these lower values compared to the control group (in $1.25 \mathrm{~mL} 4 \mathrm{hs}$ and $1.6 \mathrm{ml}$ of 48 hours), results indicating that the animals treated with the Cortvet Pet ${ }^{\circledR}$ product had a lower production of inflammatory exudate in response to the inflammatory stimulus produced by carrageenan. The results found in the present study resemble the results shown for the volumes of exudate collected in experimental tissue models observed by other authors, who they stated that there are variations between species, as well as production volume and reduced time in the amount of exudate collected in the treated animals compared to control animals..$^{21,26,28}$

In relation to the prostaglandin concentration $\left(\mathrm{PGE}_{2}\right)$, significant statistical differences $(p<0.05)$ were observed between the test and control groups, for the results found for the collection times of $12 \mathrm{~h} ; 24 \mathrm{~h}$ and 48h min (Table 3) (Figure 2) (Figure 3) post-administration of the oral dexamethasone-containing product. There was a lower production of $\mathrm{PGE}_{2}$ in the animals of the test group, whereas in the control group the concentration of $\mathrm{PGE}_{2}$ was higher in response to the inflammatory stimulus produced by carrageenan (Figure 2) (Figure 3). $\mathrm{PGE}_{2}$ is an important lipid mediator acting in active inflammatory process $^{11}$ promoting local vasodilation, attraction and activation of neutrophils, macrophages and mast cells, immune system cells present in the early stages of inflammation..$^{30}$ The steroidal anti-inflammatory drugs are inhibitors of the synthesis of $\mathrm{PGE}_{2} \cdot{ }^{14} \mathrm{~T}$ The release of eicosanoid mediators (prostaglandins, thromboxane, leukotrienes and lipoxins) is critical to $^{18}$ acute inflammatory process and many components of inflammation such as pain and fever may be exacerbated by eicosanoids. Inhibition of the formation of eicosanoids produces signs of inflammation. Corticosteroids are related to induction of protein synthesis inhibiting phospholipase $\mathrm{A}_{2}$ and thus suppression of the conversion of arachidonic acid into prostaglandin. ${ }^{12}$

Table 2 Comparison of the volume of inflammatory exudate collected during the study between the experimental groups, periods I and 2

\begin{tabular}{|c|c|c|c|c|c|}
\hline \multirow{2}{*}{ Time } & \multicolumn{2}{|l|}{ Test group } & \multirow[b]{2}{*}{ p (significance) } & \multicolumn{2}{|c|}{ Control group } \\
\hline & Average* & Standard deviation* & & Average* & Standard deviation* \\
\hline $00 \mathrm{~h} 30$ & 1.19 & 0,113 & 0.858 & 1.18 & 0.158 \\
\hline $01 \mathrm{~h} 30$ & 1.15 & 0.131 & 0.717 & 1.18 & 0,139 \\
\hline $04 \mathrm{~h} 00$ & 1.09 & 0.136 & $0.040^{\mathrm{A}}$ & 1.25 & 0.151 \\
\hline 08h00 & 0.95 & 0.131 & $<0.000 I^{A}$ & 1.34 & $0,|4|$ \\
\hline $12 \mathrm{~h} 00$ & 0.80 & 0.076 & $<0.000 \mathrm{I}^{\mathrm{A}}$ & 1.43 & 0,149 \\
\hline $24 \mathrm{~h} 00$ & 0.68 & 0.104 & $<0.000 \mathrm{I}^{\mathrm{A}}$ & 1.50 & 0.107 \\
\hline $48 \mathrm{~h} 00$ & 0.48 & 0.089 & $<0.000 I^{A}$ & 1.60 & 0.107 \\
\hline
\end{tabular}

*,Averages and standard deviations of the 08 animals (periods I and 2).

A, represents statistical difference between groups $(p<0.05)$.

Table 3 Comparison of mean concentrations of $\mathrm{PGE}_{2}$ between the experimental groups during the study, periods I and 2 .

\begin{tabular}{|c|c|c|c|c|c|}
\hline \multirow{2}{*}{ Time } & \multicolumn{2}{|c|}{ Test Group } & \multirow[b]{2}{*}{ P (significance) } & \multicolumn{2}{|c|}{ Control group } \\
\hline & Average* & Standard deviation* & & Average* & Standard deviation* \\
\hline $00 \mathrm{~h} 30$ & $|5.8|$ & 0.567 & 0.092 & 15.38 & 0.385 \\
\hline $01 \mathrm{~h} 30$ & 19.26 & 3,383 & 0.451 & 18.26 & $\mathrm{I}, 372$ \\
\hline 04h00 & 18.16 & 1,166 & 0.824 & 17.99 & 1.846 \\
\hline $8 \mathrm{~h} 00$ & 304.68 & 62,498 & 0.060 & 408.30 & 128,626 \\
\hline $12 \mathrm{~h} 00$ & 306.93 & 60,820 & $0.006^{A}$ & 430.50 & 88,098 \\
\hline $24 \mathrm{~h} 00$ & 309.93 & 75,545 & $0.008^{A}$ & 430.71 & 80,742 \\
\hline $48 \mathrm{~h} 00$ & 315.73 & 28,992 & $0.00 I^{A}$ & 447.61 & 74,601 \\
\hline
\end{tabular}

*,Averages and standard deviations of the 08 animals (periods I and 2).

A, represents statistical difference between groups $(p<0.05)$. 


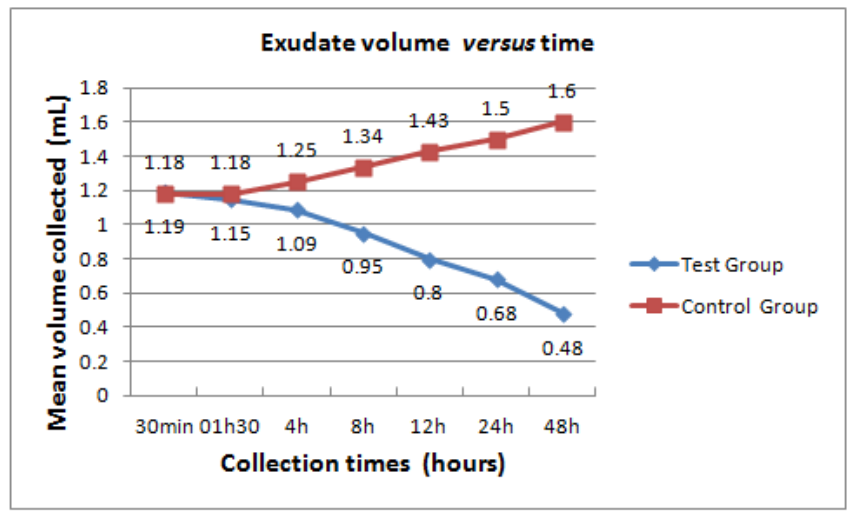

Figure I Mean volume of inflammatory exudate collected from experimental groups periods $\mathrm{I}$ and 2 .

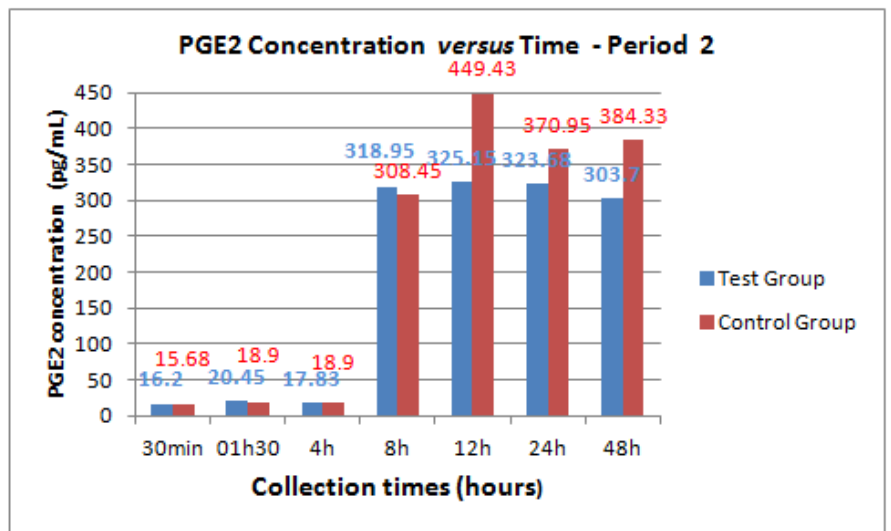

Figure 3 Results of prostaglandina quantification $\left(\mathrm{PGE}_{2}\right)$ from experimental groups in period 2.

\section{Conclusion}

The results obtained in this study demonstrated the antiinflammatory efficacy of the product Cortvet Pet ${ }^{\circledR}$ (UCBVET Saúde Animal), the dexamethasone base, for dogs in tablet form. The data also showed that the product reduced the production of inflammatory exudate decreased as the concentration of $\mathrm{PGE}_{2}$ inflammatory marker exudates of treated animals with the product.

\section{Acknowledgments}

None.

\section{Conflict of interest}

The author declares no conflict of interest.

\section{References}

1. Adcock IM, Ito K. Glucocorticoid pathways in chronic obstructive pulmonary disease therapy. Proc Am Thorac Soc. 2005;2(4):313-319.

2. Aliyu YO. Endocrine Pharmacology. In: Veterinary Pharmacology. 1st ed. Zaria, Nigeria: Tamaza Publishing Company Limited; 2007. 304 p.

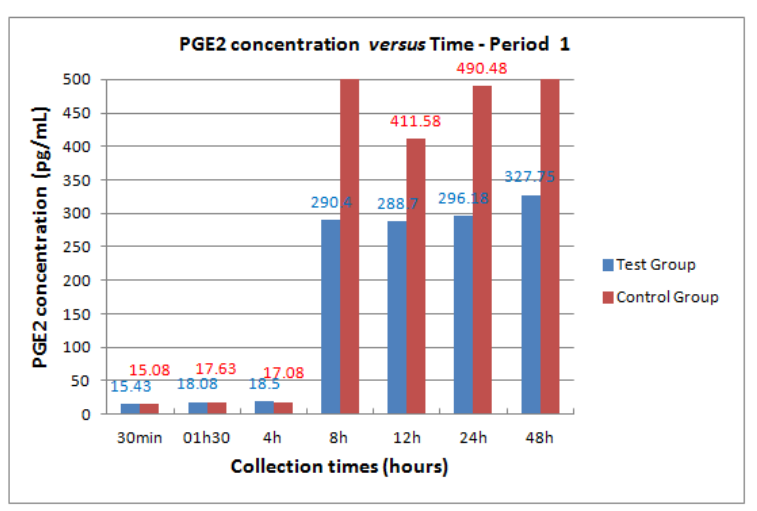

Figure 2 Results of prostaglandina quantification $\left(\mathrm{PGE}_{2}\right)$ from experimental groups in period $\mathrm{I}$.

3. Andrade MMJ, Demarch V. Steroidal anti-inflammatory drugs. In: Spinosa HS, et al. editors. Pharmacology applied to veterinary medicine, $4^{\text {th }}$ ed. Brazil, Riode Janeiro: Guanabara Koogan; 2006. p. 273-285.

4. Andrews AH, Laven R, Maisey I. Treatment and control of an outbreak of fat cow syndrome in a large dairy herd, Vet Rec. 1991;129(10):216-219.

5. Bavaresco I, Bernardi A, Battastini AMO. Glucocorticoids: Classic uses in the treatment of cancer. Infarma. 2005;17(7/9):58-60.

6. Behrend EN, Kemppainen RJ. Glucocorticoid therapy: Pharmacology, indications and complications. Vet Clin North Am Small Anim Pract. 1997;27(2):187-213.

7. Boothe DM, Mealey KA. Glucocorticoid therapy in the dog and cat. In: Boothe DW editor. Small Animal Clinical Pharmacology and Therapeutics. Philadelphia, WB Saunders; 2001. p. 313-329.

8. Cole MA, Kim PJ, Kalman BA, et al. Dexamethasone suppression of corticosteroid secretion: evaluation of the site of action by receptormeasures and functional studies. Psychoneuroendocrinology. 2000;25(2):151-167.

9. Derendorf $\mathrm{H}$, Hochhaus G, Ollmann M, et al. Receptorbased pharmacokinetic pharmacodynamics analysis of corticosteroids. J Clin Pharmacol. 1993;33(2):115-123.

10. Ferreira SH, Cunha FQ, Lorenzetti BB, et al. Role of lipocortin-1 in the anti-hyperalgesic actions of dexamethasone. $\mathrm{Br} J$ Phamacol. 1997;121(5):883-888.

11. Gonzalez-Rey E, Chorny A, Del Moral RG. et al. Therapeutic effect of cortistatin on experimental arthritis by down regulating inflammatory and Th1 responses. Ann Rheum Dis. 2007;66(5):582-588.

12. Goodman, Gilman. The pharmacological basis of therapeutics. $10_{\text {th }}$ ed. Riode Janeiro: McGraw-Hill; 2003.

13. Higgins AJ, Lees P, Wright JA. Tissue cage model for collection of inflammatory exudate in ponies. Res Vet Sci. 1984;36(3):284-289.

14. Kalinski P. Regulation of immune response by prostaglandin E2. $J$ Immunol. 2012;188(1):21-28.

15. Kaneko JJ, Harvey JW, Bruss ML. Clinical Biochemistry of Domestic Animals. 6th ed. USA, San Diego: Academic Press; 2008.

16. Kayser V, Guilbaud G. Local and remote modifications of nociceptive sensitivity during carrageenin- induced inflammation in the rat. Pain. 1987;28(1):99-107. 
17. Langston VC. Therapeutic Management of Inflammation. In: Howard JL, et al. editors. Current veterinary therapy 4: food animal practice. USA, Philadelphia: Saunders; 1999. p. 7-12.

18. Lees P, Higgins AJ, Sedwick AD, et al. Veterinary Record. 1987;120:522.

19. Salerno A, Hermann R. Efficacy and safety of steroid use for postoperative pain relief. Update and review of the medical literature. $J$ Bone Joint Surg Am. 2006;88(6):1361-1372.

20. McDonald LE. Hormones that influence metabolism. In: Booth NH, et al. editors. Pharmacology and veterinary therapeutics. 6th ed. Riode Janeiro: Guanabara Koogan; 1992. p. 493-526.

21. McKellar QA, Lees P, Gettinby G. Pharmacodynamics of tolfenamic acid in dogs. Evaluation of dose response relationships. Eur J Pharmacol. 1994;253(3):191-200.

22. Pierre-Louis T. Anti-inflammatory agents, In: Mercks Veterinary Manual. Synthias MK, editor. 10th ed. White House Station, USA Merck and Co, Inc; 2010. p. 2313-2328.

23. Platt SR, Abramson CJ, Garosi LS. Administering corticosteroids in neurologic diseases. Compendium. 2005:210-228.

24. Rang HP, Dale MM, Ritter JM. Pharmacology. 6a ed. Brazil, Riode Janeiro: Elsevier; 2007.

25. S chimer BP, $\mathrm{P}$ arker KL. Adrenocortical steroids and their synthetic analogs. In: Hardman JG, et al. editors. Goodman and Gilman's The Pharmacological Basis of Therapeutics. 10th ed. New York, NY: McGrawHill; 2001. p. 1665-1666.
26. Sidhu P, Shojaee Aliabadi F, Andrews M, et al. Tissue chamber model of acute inflammation in farm animal species. Res Vet Sci. 2003;74(1):67-77.

27. Verri WA Jr, Cunha TM, Parada CA, et al. Hypernociceptive role of cytokines and chemokines: targets for analgesic drug development? Pharmacol Ther. 2006;112(1):116-138.

28. Vinegar R, Truax JF, Selph JL, et al. Pathway to carrageenan-induced inflammation in the hind limb of the rat. Fed Proc. 1987;46(1):118-126.

29. Wang XS, Lau HY. Prostaglandin E potentiates the immunologically stimulated histamine release from human peripheral blood-derived mast cells through EP1/EP3 receptors. Allergy. 2006;61(4):503-506.

30. Weller CL, Collington SJ, Hartnell A, et al. Chemotactic action of prostaglandin E2 on mouse mast cells acting via the receptor $\mathrm{PGE}_{2}$ 3. Proc Natl Acad Sci USA. 2007;104(28):11712-11717.

31. World health organization. $19^{\text {th }}$ Model List of Essential Medicines. WHO; 2015. $51 \mathrm{p}$.

32. Winter WA, Risley EA, Nuss GW. Carrageenan- induced edema in hind paw of the rat as an assay for anti-inflammatory drugs. Proc Soc Exp Biol Med. 1962;111:544-54. 